\title{
Forest management and the economics of carbon storage: the nonfinancial component
}

\author{
Jack K. Winjum ${ }^{1}$, David K. Lewis ${ }^{2}$ \\ ${ }^{1}$ National Council for Air and Stream Improvement, U.S. EPA Environmental Research Laboratory, 200 SW 35th St., \\ Corvallis, Oregon 97333 , USA \\ ${ }^{2}$ Department of Forestry, Oklahoma State University, Stillwater, Oklahoma 74078-0491, USA
}

\begin{abstract}
Globally, forests fix and store significant amounts of carbon. This attribute aids in reducing the buildup of atmospheric $\mathrm{CO}_{2}$. Forest management can increase biomass productivity on lands suitable for forest growth thereby enhancing the uptake of $\mathrm{CO}_{2}$ by terrestrial ecosystems. Worldwide, however, only about $10 \%$ of the 3.6 billion ha of forests are currently under management, suggesting a considerable potential for expansion. Before national and international policy makers commit to increasing the level of forest management, they need information on the benefits and costs of forest management for this objective. Financial evaluations of forest management benefits and costs are not uncommon. But nonfinancial considerations are often not considered in such analyses, and they can change resulting conclusions. Using a series of 30 plantation regimes from around the world, this paper demonstrates the influence of including the nonfinancial cost (i.e. opportunity cost) of forest growing stock in selecting the most favorable opportunities for investments in carbon storage through forest management.
\end{abstract}

\section{INTRODUCTION}

Interest has grown internationally in the past decade for stepping up management of world forests. Interests stem from sustaining basic forest resources, reducing deforestation, restoring degraded lands, and protecting biodiversity. Current interest also stems from the potential of forest management to enhance global carbon fixation and storage within forest biomes (Dixon et al. 1991, Trexler 1991). Decisions to expand forest management throughout the world will hinge on many biological, social-political, and economic considerations.

This paper focuses on the economic considerations of forest management for carbon storage, and argues for the need to include nonfinancial benefits and costs. The nonfinancial components are often not considered in forest economic analysis (e.g. Sedjo 1983, Dixon et al. 1991, and the National Forest Management Plans for the U.S. South, USDA Forest Service 1985). The term nonfinancial is defined later, but examples of nonfinancial components of managed forests are biodiversity, aesthetics, and the opportunity cost of the growing stock. Using a series of plantation management regimes developed by Sedjo (1983), an economic analysis which includes growing stock costs is developed to illustrate these points.

\section{Background}

Biologically, the potential of forest management for carbon storage appears quite attractive. Global forests fix and store significant amounts of carbon because of their large biomass (62\% of all terrestrial carbon is stored in forests; Waring \& Schlesinger 1985) and vast size (one-third of the world's land area; WRI 1990). Forest management can enhance carbon fixing and storage of terrestrial ecosystems. Practices such as silvicultural tending of existing stands or establishing new forest plantations can increase biomass productivity on lands suitable for forest growth (Farnum et al. 1983, Zobel et al. 1987, Hughes 1991).

Worldwide, forests occupy 3.6 billion ha, yet only about $10 \%$ are currently under some form of active management (Mather 1990, Allan \& Lanly 1991, WRI 
1990, Laarman \& Sedjo 1992). This suggests a potential to expand forest management in the world which could aid in mitigating the buildup of atmospheric $\mathrm{CO}_{2}$ by terrestrial ecosystems. Winjum et al. (1992) estimated that expanding world forest management to over 600 million to 1200 million ha during the next 50 yr may be possible, and that such expansion could sequester 50 to 100 (metric) gigatons of carbon (Gt C). Using today's anthropogenic emission rates, 300 to 400 Gt of carbon will be released to the atmosphere in the same period (Schneider 1989). By comparison, therefore, expanding forest management would be a significant aid in mitigating against the increasing atmospheric $\mathrm{CO}_{2}$ and the onset of global warming.

Socially and politically, momentum has grown in the world toward increasing forest management that facilitates, where appropriate, both conservation and sustainable development of forest resources. The 51 Forest Principles agreed upon by over 100 nations at the Earth Summit in Brazil during June 1992 had exactly such a target (Heiner 1992, UNCED 1992). Reaching consensus on the Principles is clearly a step toward increased social and political support for expanded global forest management.

\section{Economic considerations}

The economics of carbon storage through forest management are less clear (Swisher 1991, Trexler 1991). Implementation of policies to expand world forest management to mitigate increasing atmospheric $\mathrm{CO}_{2}$ will require substantial resources (Van Kooten 1991. Rubin et al. 1992). Before such large-scale efforts are undertaken, policy makers will require an understanding of the potential goods and services produced, and for each good and/or service, the value of the benefits and costs in quantitative terms (Barlowe 1978). For forests, such quantification is not always straightforward, but to the extent that the value of forest benefits and costs can be quantified, management decision making is facilitated (Kramer et al. 1992).

\section{FOCUSING THE ECONOMICS OF FOREST MANAGEMENT FOR C STORAGE}

Complex economic evaluations are typically approached by the method of abstraction or partial analysis since accounting for every aspect is beyond present understanding (Duerr 1960). Forest economics is a case in point, particularly when valuing forest management for the purpose of carbon storage. Thus, some focusing steps are called for and are offered in this paper.
To begin, forests afford humans a broad array of direct and indirect needs. The direct needs are commonly called goods and services, and typical examples (adapted from Smith 1992) are:

\begin{tabular}{ll} 
Goods & Services \\
\hline Fuelwood & Recreation \\
Pulpwood & Biological diversity \\
Sawlogs & Landscape diversity \\
Water & Soil conservation \\
Wildlife & Amenity functions \\
Botanical yields & Pollutant sequestration
\end{tabular}

More could be added to both lists. Here, carbon storage falls within the broader service of pollutant sequestration.

In the economic evaluation of alternative choices regarding forest use, the benefits are either direct or indirect depending on their role in and level of economic activity (Miller \& Blair 1985). Indirect contributions from forests providing goods and services include such items as employment for local people and the development of social infrastructure (from a portion of the revenues). Examples of such social benefits are transportation, schools, and governing systems. Marketdriven prices reflecting values have been established for some direct forest benefits. The indirect benefits have not commonly been valued by market prices, and therefore as one focusing measure, this paper concentrates only on the direct impacts of carbon storage.

The next step is to determine the values for the benefits and costs of the direct goods and services. Again, the values of forest benefits and costs have historically been quantified with market-driven dollar amounts paid for commercial goods that flow from the forest (Dawkins 1972, Kessler et al. 1992). In recent years, economists have recognized forest values beyond the flow of commercial goods. For example, the forest has an aesthetic or non-consumptive value to many individuals, and from the broader social standpoint, it is now seen that there is great forest value in storing carbon (Kramer et al. 1992). Thus the stock in the forest as a resource has recognized value in addition to the goods and services that are produced and flow from the stock. This value also represents an element of the cost of forest management and will be discussed in more detail below.

Basically, values arise from the choices made by individuals and by societies (Samuelson 1964, Trexler 1991). The objective is different according to whether choices are made by individuals or by decision makers in the public agencies of society. Individuals make choices to maximize wealth, generally their own or a special interest group (Hirshleifer 1970). Societies, on the other hand, function most equitably when making choices in such a way that at least one person is better 
off and no one is worse off so that the net social welfare is increased (Winch 1971).

These 3 components (who, what, and for how much) when placed in a simple matrix provide a framework for further focusing of the economic evaluation of forest management for carbon storage (Table 1). In this manner, 8 cells are created. To evaluate goods and services produced by a forest, it is necessary to first identify who the decision maker is for a particular output and whether it is a good or a service, i.e. cell 1, 2, 3 or 4 . Second, a value is placed on the benefit (b) and the cost (c). Examples of these 8 cells are given in Table 1

Goods provided by the forests may be evaluated by financial means in the presence of competitive markets, but dealing with the stock of the standing forest calls for a nonfinancial approach. By definition, financial benefits and costs are defined as monetary values that would be reflected in a standard financial budget or accounting statement. Nonfinancial or non-market benefits and costs are reflections of the desirability of goods and services associated with forests which are not actively traded in financial markets. Examples besides growing stock are biodiversity and aesthetic characteristics.

A measure of value is required for either financial or nonfinancial evaluations. This is especially true for the array of benefits and costs associated with forest management (i.e. cells $1 \mathrm{~b}$ through $4 \mathrm{c}$ of Table 1 ). In the case of financial analysis, these values are based on monetary prices established through market exchanges. For nonfinancial analyses, the values are also expressed as monetary prices which allow the summing of and comparison within and between alternatives

Monetary prices established through market transactions may also represent social values (i.e. cells $3 \mathrm{~b}$, $3 c, 4 b$, and $4 c$ of Table 1). However, if markets are incomplete or non-competitive, market prices may not represent social values (Hirshleifer 1970). In the event of an absence of prices representing social value, numerical estimates of social value can be estimated and utilized as 'accounting' prices (Little \& Mirrlees 1974). An example is the incorporation of environmental costs in the decision making for developing new electrical utilities (Palmer \& Krupnich 1991). These accounting prices may deviate significantly from explicit prices under conditions of incomplete or noncompetitive markets, but they are intended to express social values that are ignored by existing markets (Sinden \& Worrell 1979).
Recent work by Dixon et al. (1991) is an example of a financial assessment of the costs of forest management practices for the purpose of carbon fixation and storage. For example, considering just financial costs of implementing reforestation over a $50 \mathrm{yr}$ period, the cost in 1990 US $\$$ per metric ton of carbon sequestered was $\$ 8, \$ 6$, and $\$ 7$ in the boreal, temperate, and tropical regions, respectively.

In addition to financial costs, the traditional and direct economic costs associated with forest management also include the cost of waiting for tree harvests. That is, there is a cost associated with establishing a plantation and waiting some period of time before harvest. This cost is classed as a nonfinancial cost and is the cost associated with the opportunities forgone by having money invested in the use of resources such as forest land and its growing stock until tree harvest, i.e. the opportunity cost of managing a forest for timber yields. Because forests are a form of biological or genetic production, where the producing unit is also the desired product or service, these costs are significant to forest management decisions (Duerr 1988). To illustrate, the plantation analysis below focuses on the significance of forest stock opportunity cost.

\section{METHODS}

For the analysis, the value of the growing stock is computed for 30 plantation regimens developed by Sedjo (1983). The resulting values allow a comparison of the carbon storage costs with: (1) financial costs alone; (2) plantation revenues included; and (3) net 
costs determined particularly (a) with and (b) without an element of nonfinancial costs considered.

Sedjo's representative plantations. Sedjo (1983) developed a model to simulate the productivity, costs, and revenues of a series of over 30 plantations of the world. The purpose was to compare the productive potential and monetary returns of forest plantations representative of major forested regions throughout the world. The simulations were based upon data for actual plantations as reported in the literature or obtained from credible experts associated with welldocumented plantations. For this analysis, 30 of the simulated plantations were selected that represented 18 temperate and 12 tropical forest regions or nations of the world (Table 2). Plantation species were mostly of coniferous genera (Pinus and Pseudotsuga) though 2 hardwood examples are included (Gmelina and Eucalyptus). Both short-rotation pulpwood crops and longer-rotation sawlog crops with pulpwood thinnings were considered.
Cost of the forest stock. The amount of growing stock of a forest stand is commonly expressed as the stemwood volume of the commercially valuable trees at any given age. For example, a plantation of loblolly pine Pinus taeda in the southeastern United States is estimated to have $258 \mathrm{~m}^{3} \mathrm{ha}^{-1}$ of stemwood volume or growing stock at age 30 , i.e. representative plantation no. 1 from Sedjo (1983) (Table 3, Fig. 1). At the time of final harvest, the volume of growing stock and its value are equal to the stand yield and its value. In this example, $258 \mathrm{~m}^{3} \mathrm{ha}^{-1}$ is the yield valued at a price of $\$ 18.94$ per $\mathrm{m}^{3}$ for loblolly pine at $30 \mathrm{yr}$ (Table 3 ; all dollars in this paper are 1979 US\$).

However, a fully regulated series of plantations that would produce this level of yield and value on an annual basis would have to comprise 31 ha. This provides 1 ha of each age-class year plus 1 ha for the 0 age-class available for reforestation annually. The growing stock volume of the 31 ha forest would equal

Table 2. Representative plantation regimes used for analysis in this paper and their rotation ages (Sedjo 1983)

\begin{tabular}{|c|c|c|c|c|}
\hline \multirow[t]{3}{*}{ Region/Species } & \multicolumn{4}{|c|}{ Regime } \\
\hline & \multicolumn{2}{|c|}{ Pulpwood } & \multicolumn{2}{|c|}{$\begin{array}{c}\text { Integrated, with standard- } \\
\text { quality sawtimber }\end{array}$} \\
\hline & Plantation no. & Rotation age (yr) & Plantation no. & Rotation age (yr) \\
\hline \multicolumn{5}{|l|}{ North America } \\
\hline Pinus taeda, average-yield site & \multicolumn{4}{|c|}{ U.S. South } \\
\hline Pinus taeda, high-yield site & 3 & 30 & 4 & 35 \\
\hline \multicolumn{5}{|l|}{ Pacific Northwest } \\
\hline Pseudotsuga menziesii, average-yield site & 5 & 40 & 6 & 50 \\
\hline Pseudotsuga menziesii, high-yield site & 7 & 30 & 8 & 40 \\
\hline \multicolumn{5}{|l|}{ South America } \\
\hline \multicolumn{5}{|l|}{ Brazil, Amazonia } \\
\hline Pinus caribaea & 9 & 12 & 10 & 16 \\
\hline Gmelina spp. & 11 & 19 & 12 & 12 \\
\hline \multicolumn{5}{|l|}{ Brazil, central } \\
\hline Eucalyptus spp. & 13 & 19 & 14 & 19 \\
\hline \multicolumn{5}{|l|}{ Brazil, southern } \\
\hline Pinus taeda & 15 & 12 & 16 & 20 \\
\hline \multicolumn{5}{|l|}{ Chile } \\
\hline Pinus radiata & 17 & 25 & 18 & 32 \\
\hline \multicolumn{5}{|l|}{ Oceania } \\
\hline \multicolumn{5}{|l|}{ Australia } \\
\hline Pinus radiata & 19 & 29 & 20 & 35 \\
\hline \multicolumn{5}{|l|}{ New Zealand } \\
\hline Pinus radiata & 21 & 18 & 22 & 27 \\
\hline \multicolumn{5}{|l|}{ Africa } \\
\hline \multicolumn{5}{|l|}{ South Africa } \\
\hline Pinus patula & 23 & 15 & 24 & 26 \\
\hline \multicolumn{5}{|l|}{ Gambia-Senegal } \\
\hline Gmelina spp. & 25 & 30 & 26 & 40 \\
\hline Eucalyptus spp. & 27 & 21 & 28 & 30 \\
\hline \multicolumn{5}{|l|}{ Asia } \\
\hline Borneo & & & & \\
\hline Pinus caribaea & 29 & 15 & 30 & 20 \\
\hline
\end{tabular}


Table 3. Representative Plantation 1 in southern USA: Pinus taeda on an averageyield site managed as a pulpwood regime with 2 commercial thinnings and harvest at age 30 yr. Associated costs, stumpage prices and yield are as presented by Sedjo (1983)

\begin{tabular}{|llrrr|}
\hline Year & Practice & $\begin{array}{c}\text { Cost } \\
\left(\$ \mathrm{ha}^{-1}\right)\end{array}$ & $\begin{array}{c}\text { Stumpage price } \\
\left(\$ \mathrm{~m}^{-3} \mathrm{ha}^{-1}\right)\end{array}$ & $\begin{array}{c}\text { Yield } \\
\left(\mathrm{m}^{3} \mathrm{ha}^{-1}\right)\end{array}$ \\
\hline 0 & Site preparation & 180.75 & & \\
0 & Planting & 83.42 & & \\
$0-30$ & Stand protection (per year $)$ & 2.00 & & \\
4 & Hardwood control & 69.52 & & 49.31 \\
10 & Controlled burning & 11.63 & & 49.31 \\
17 & Pulpwood commercial thinning & & 14.94 & \\
22 & Pulpwood commercial thinning & & 14.94 & 258.05 \\
30 & Pulpwood harvest & & 18.94 & \\
\hline
\end{tabular}

ing stock valued at $\$ 63615$ to produce $258 \mathrm{~m}^{3}$ of pulpwood each year instead of liquidating the plantation to generate $\$ 63615$ in revenue. Opportunity costs for stocks of nondepreciable capital, like forest growing stock, are usually estimated as a rent for the use of productive assets. The rent is based on a discount rate, expressed as a percent, which is the price of deferred consumption. In this study, the annual rate used was $5 \%$, a real rate of interest commonly used in forest economic analysis which is net of inflation and risk (Davis \& Johnson 1987). That is, $5 \%$

the sum of the growing stock on each of the hectares that make up the forest or $3982 \mathrm{~m}^{3}$ with a value of $\$ 63615$ (Tables 4B \& 5).

The nonfinancial opportunity costs are again the implicit costs representing the opportunities forgone by the use of assets for a given purpose (Samuelson 1964) and are an important consideration. In this example, the opportunity cost is the cost of using the $3982 \mathrm{~m}^{3}$ of grow- of the growing stock value, $\$ 63615$, is $\$ 3181$ (Table 5). This amount is estimated as the annual opportunity cost (nonfinancial) of using the growing stock to produce pulpwood for a year (adapted from Duerr 1988).

Costs of carbon stored. The next step in determining costs of storing carbon is to divide costs and revenues in Table 5 by 31 ha to obtain average per-

hectare values (Table 6). This allows comparisons

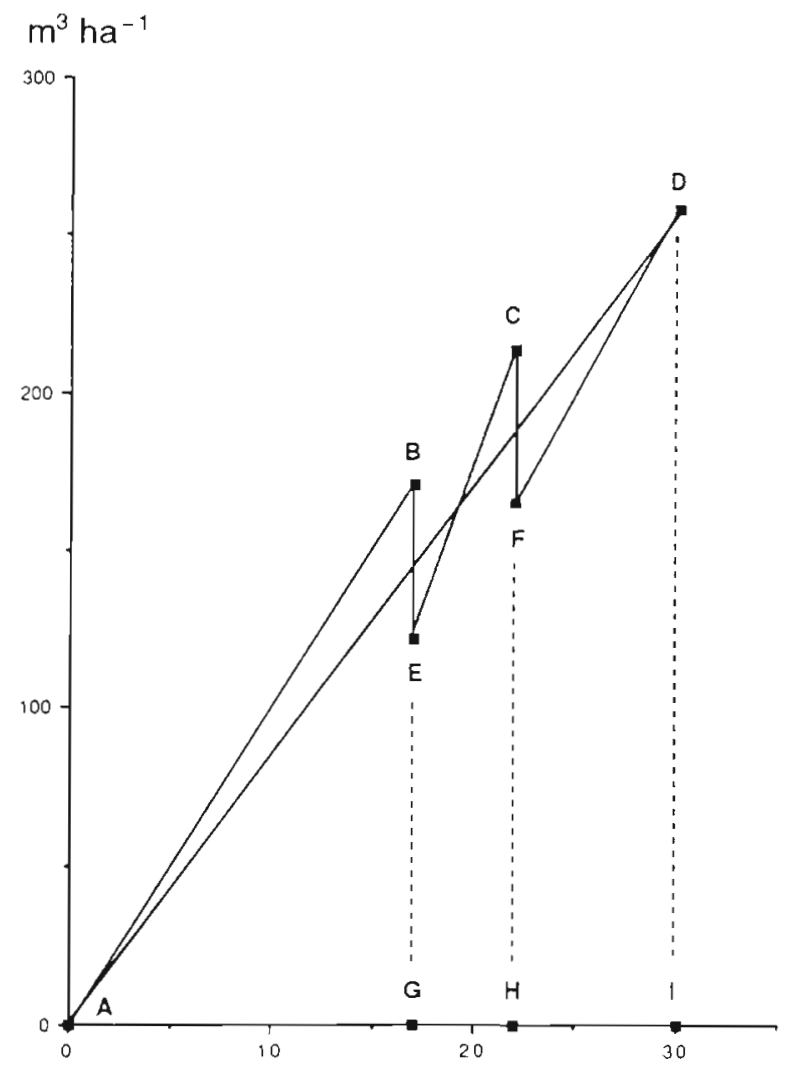

(a) age, in years; or

(b) area of fully regulated forest, in hectares
Fig. 1. Graphic illustration of the pulpwood regime for representative Plantation 1 (Table 3). The graphic serves 2 roles for this analysis depending upon the label for the horizontal axis: (a) time (yr) or (b) area (ha). The same procedure was used for all 30 representative plantations in Table 2. Fig. 1a shows simplified per-hectare growth curves and wood yields for Plantation 1. From Table 3 , the final harvest yields $258 \mathrm{~m}^{3}$ $\mathrm{ha}^{-1}$ at $30 \mathrm{yr}$. Therefore, the line AD is a simplified plantation growth curve (though in reality, such forest growth curves are usually 'S' shaped). Lines BE and CF represent the $49 \mathrm{~m}^{3} \mathrm{ha}^{-1}$ yields for the commercial thinnings at 17 and 22 yr, respectively. For simplicity, it was assumed that half of each yield occurred at points above and below line $\mathrm{AD}$. In this manner, the overall growth curve for the plantation is represented by AB-BE-EC-CF-FD with a total plantation yield of $356 \mathrm{~m}^{3} \mathrm{ha}^{-1}$ $\left(49+49+258 \mathrm{~m}^{3} \mathrm{ha}^{-1}\right.$ as in Table $\left.4 \mathrm{~A}\right)$. Fig. $1 \mathrm{~b}$ places Plantation 1 in the context of a 31 ha fully regulated forest. The forest has 1 ha for each age class in the 30 yr rotation plus 1 recently harvested hectare (at 0 on the horizontal axis) ready for reforestation annually. The growing stock was computed for 3 plantation periods plus the total as follows (also see Table 4B):

(i) before the first commercial thinning (area $A B G$ on the graph) $=1452 \mathrm{~m}^{3}$

(ii) between the 2 thinnings (area ECHG) $=839 \mathrm{~m}^{3}$;

(iii) between the second thinning and final harvest at the 30 yr rotation age (area $\mathrm{FDIH})=1691 \mathrm{~m}^{3}$;

(iv) total (area bounded by lines $A B, B E, E C, C F, F D, D I$, and $\left.I A=1452+839+1691 \mathrm{~m}^{3}\right)=3982 \mathrm{~m}^{3}$ 
Table 4. Growing stock, yields, and dollar values for representative Plantation 1 (Table 3)

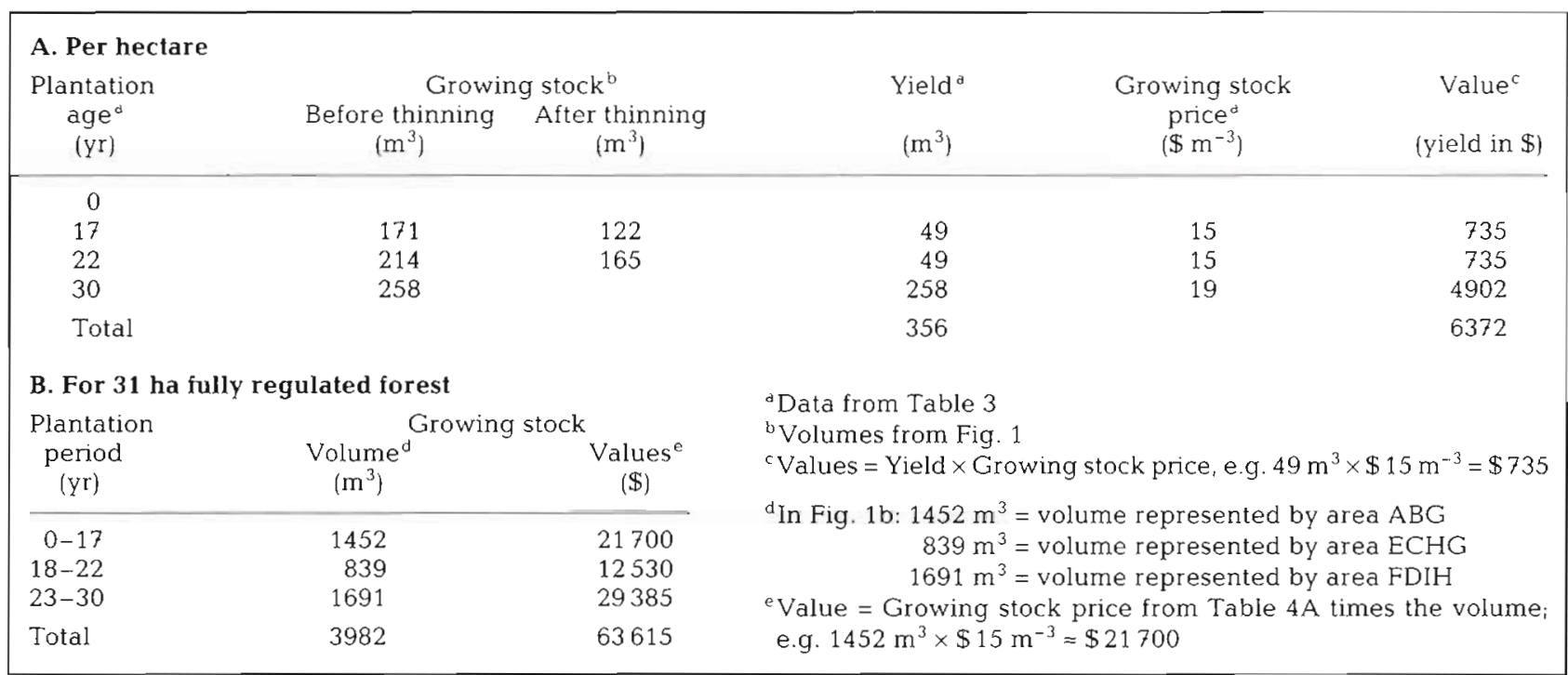

between forest of different sizes, though in reality the average hectare in a fully regulated forest does not exist. Stemwood volume can be converted to

Table 5. For Plantation 1, a summary of calculated values for volumes, costs, growing stock value, carbon stored, and revenues developed from data for a 31 ha fully regulated forest, given in Tables $3 \& 4$. Similar values were calculated for 30 representative plantations from Sedjo (1983)

\begin{tabular}{|c|c|c|c|}
\hline \multirow[t]{2}{*}{ Item } & \multicolumn{3}{|c|}{ Units } \\
\hline & $m^{3}$ & $\$$ & t C \\
\hline \multicolumn{4}{|l|}{ Growing stock } \\
\hline Volume & 3982 & & \\
\hline Value & & 63615 & \\
\hline Carbon stored & & & 1497 \\
\hline \multicolumn{4}{|l|}{ Annual growth } \\
\hline Volume & $356^{\mathrm{d}}$ & & \\
\hline Value & & 6372 & \\
\hline Carbon stored & & & 134 \\
\hline \multicolumn{4}{|l|}{ Costs $\left(\$ y r^{-1}\right)$} \\
\hline \multicolumn{4}{|l|}{ Financial } \\
\hline Site preparation & & 181 & \\
\hline Planting & & 83 & \\
\hline Stand protection $\left(\$ 2 \mathrm{ha}^{-1}\right)$ & & 62 & \\
\hline Hardwood control & & 70 & \\
\hline Controlled burn & & 12 & \\
\hline Sub-total & & 408 & \\
\hline \multicolumn{4}{|l|}{ Nonfinancial } \\
\hline Growing stock & & $3181^{b}$ & \\
\hline Total annual costs & & 3589 & \\
\hline Annual revenues & & 6372 & \\
\hline \multicolumn{4}{|c|}{$\begin{array}{l}{ }^{2} \text { Annual growth = annual yield in a fully regulated forest } \\
\text { bNonfinancial growing stock costs equal } 5 \% \text { of growing } \\
\text { stock value }\end{array}$} \\
\hline
\end{tabular}

metric tons of carbon per hectare ( $\mathrm{C} \mathrm{ha} \mathrm{h}^{-1}$ ) using formulas explained by Dixon et al. (1991). These yields in $\mathrm{t} \mathrm{C} \mathrm{ha-1}$ were divided into 6 types of per-hectare costs: (1) financial costs; (2) growing stock costs; (3) gross costs (the sum of 1 and 2); (4) revenues; and (5) 2 net costs, (a) with growing stock (the sum of 3 and 4) and (b) without growing stock (the sum of 1 and 4). Results produce costs in $\$ \mathrm{t}^{-1} \mathrm{C}$. In these 6 ways, values in $\$ t^{-1} \mathrm{C}$ were computed for each of Sedjo's 30 simulated plantations.

Table 6. Per-hectare data calculated for representative Plantation 1 from Table 5

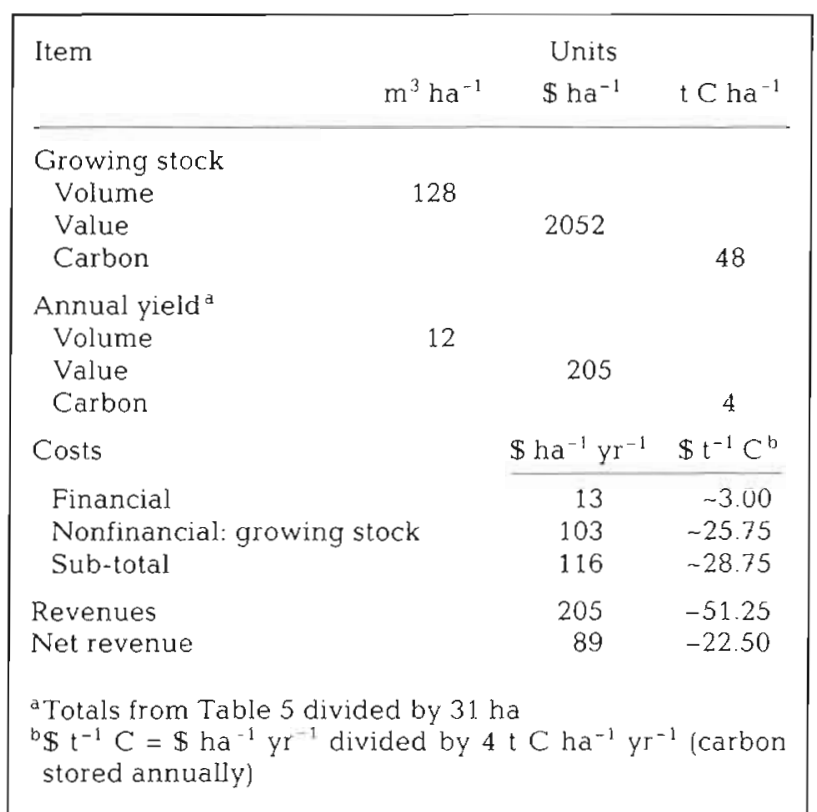




\section{RESULTS}

Among the 6 cost calculations, results vary as to which region (temperate versus tropical) or which plantation regime (pulpwood versus integrated) is the more attractive investment regarding carbon storage by reforestation. The differences, where significant, illustrate how nonfinancial, as well as financial, components of economic analyses are important to evaluating the cost of carbon storage through forest management. Differences between regions and regimes were tested for statistical significance by the non-parametric Wilcoxon 2-sample test using 0.05 as the level of probability for acceptance of significant differences between median values (Devore \& Peck 1986).

Financial costs. The financial cost of producing a ton of carbon by reforestation in Sedjo's 30 simulated situations ranges from about $\$ 1$ to $\$ 10$ (Table 7 ). Temperate region plantations store carbon by this financial criterion at significantly less cost than for those in the tropical region. Median values are: temperate, $\$ 4 \mathrm{t}^{-1} \mathrm{C}$; and tropical, $\$ 7 \mathrm{t}^{-1} \mathrm{C}$ (Table 8 ). By the Wilcoxon test, the temperate median is significantly different from the tropical median. No significant differences were evident between plantation regimes, i.e. the pulpwood versus integrated.

Growing stock costs. The cost of maintaining plantation growing stock relative to a ton of carbon stored in the 30 plantations ranged from $\$ 4$ to $\$ 81$ (Table 7 ). Least costs were associated with the tropical plantations. Median values are: tropical, $\$ 9 \mathrm{t}^{-1} \mathrm{C}$; and temperate, $\$ 21 \mathrm{t}^{-1} \mathrm{C}$ (Table 8 ). The 2 medians are significantly different from each other, but the difference between plantation regimes was not significant.

Gross costs. Gross costs per ton of carbon stored range from $\$ 9$ to $\$ 84 \mathrm{t}^{-1} \mathrm{C}$. Systems which have the lowest gross costs per ton of carbon are predominantly those in the tropics and those with integrated crops. Mean values are: by regions - tropics, $\$ 14 \mathrm{t}^{-1} \mathrm{C}$; and temperate, $\$ 24 \mathrm{t}^{-1} \mathrm{C}$; by crop type - integrated, $\$ 18 \mathrm{t}^{-1}$ $C_{\text {; }}$ and pulpwood, $\$ 22 \mathrm{t}^{-1} \mathrm{C}$. Between regions and plantation regimes, the medians are significantly different.

Revenues. Revenues from timber and pulpwood harvests are handied as negative costs. Median values are: temperate, $-\$ 51 \mathrm{t}^{-1} \mathrm{C}$; and tropical, $-\$ 38 \mathrm{t}^{-1} \mathrm{C}$ (Table 8 ). These medians are significantly different. The tropical revenues per ton of carbon are significantly different than those of the temperate region. Regarding plantation management, revenues per ton of carbon stored are significantly greater for integrated regimes than those for integrated pulpwood. The medians were, respectively, $-\$ 56 \mathrm{t}^{-1} \mathrm{C}$ versus $-\$ 42 \mathrm{t}^{-1}$ C (Table 8)

Net costs. When calculating net costs, distinct and important differences appear depending upon whether or not nonfinancial costs are included. That is, the net costs of storing carbon considering only financial costs range from about $-\$ 74$ to $-\$ 20 \mathrm{t}^{-1} \mathrm{C}$ (i.e. where plantation revenues are greater than costs and so are given as negative costs in Table 7). With growing stock costs accounted for, median values range from $-\$ 45$ to $-\$ 5 t^{-1} \mathrm{C}$ for 28 of the 30 plantations in the analysis, but for 2 plantations, 5 and 6 in Table 2 , the revenues did not exceed the costs. Their cost are, therefore, +4 and $+21 t^{-1} \mathrm{C}$ respectively (Table 7). Plantations 5 and 6 represent Douglas fir Pseudotsuga menziesii growing on sites of average quality in the Pacific Northwest, USA. Together, they have the longest rotation ages $(40$ and $50 \mathrm{yr}$, respectively), volumes, and values of growing stock among all 30 plantations in the analysis.

More importantly, however, significant differences between the regional medians in $\$ \mathrm{t}^{-1} \mathrm{C}$ for temperate

Table 7. Calculated costs for a ton of carbon stored for representative Plantation 1 and the range of median values for 30 plantations from the temperature and tropical regions of the world (Table 2). To illustrate the importance of considering the growing stock opportunity costs, net costs (no.5) are shown with and without this cost included

\begin{tabular}{|c|c|c|c|}
\hline \multicolumn{2}{|c|}{ Cost items } & \multirow{2}{*}{$\begin{array}{c}\text { Representative } \\
\text { Plantation } 1 \\
\left(\$ \mathrm{t}^{-1} \mathrm{C}\right)\end{array}$} & \multirow{2}{*}{$\begin{array}{c}\text { Range of medians for } \\
30 \text { plantations } \\
\left(\$ t^{-1} \mathrm{C}\right)\end{array}$} \\
\hline No. & Calculations & & \\
\hline 1. & Financial & 3.00 & 1.25 to 10.25 \\
\hline 2. & Growing stock & 25.75 & 4.00 to 80.75 \\
\hline 3. & Gross $(1+2)$ & 28.75 & 9.00 to 84.00 \\
\hline 4. & Revenue (negative costs) & -51.25 & -25.00 to -75.75 \\
\hline 5. & Net costs & & \\
\hline a. & Without growing stock $(1+4)$ & -48.25 & -73.75 to -20.00 \\
\hline b. & With growing stock $(3+4)$ & -22.50 & -45.00 to +21.00 \\
\hline
\end{tabular}


Table 8. Comparisons among regions and regimes for the calculated costs for a ton of carbon stored among the 30 representative plantations (Table 2). Median values were calculated for each subsample of size n. Paired medians were tested for significance (significant differences among pairs of medians were screened by the Wilcoxon 2 -sample test, that is, on the horizontal rows of data, medians between temperate vs tropical regions and regimes of pulpwood vs integrated crops are significantly different at the 0.05 level of probability where the letters $a$ and $b$ are noted; where no letter appears the medians are not significantly different)

\begin{tabular}{|c|c|c|c|c|c|}
\hline \multicolumn{2}{|c|}{ Cost items } & \multicolumn{4}{|c|}{ Medians $\left(\$ t^{-1} C\right)$} \\
\hline \multirow{2}{*}{ No. } & \multirow{2}{*}{ Calculations } & \multicolumn{2}{|c|}{ Regions } & \multicolumn{2}{|c|}{ Regimes } \\
\hline & & Temperate & Tropical & Pulpwood & Integrated \\
\hline 1. & Financial & $4 \mathrm{a}$ & $7 \mathrm{~b}$ & 5 & 5 \\
\hline 2. & Growing stock & $21 \mathrm{a}$ & $9 \mathrm{~b}$ & 18 & 14 \\
\hline 3. & $\operatorname{Gross}(-1+2)$ & $24 \mathrm{a}$ & $14 \mathrm{~b}$ & 22 & 18 \\
\hline 4. & Revenues (negative costs) & $-51 \mathrm{a}$ & $-38 b$ & $-42 a$ & $-56 \mathrm{~b}$ \\
\hline 5. & Net costs & & & & \\
\hline a. & Without growing stock $(\sim 1+4)$ & $-48 a$ & $-32 b$ & $-36 a$ & $-49 b$ \\
\hline b. & With growing stock $(\sim 3+4)$ & -22 & -24 & $-20 a$ & $-32 b$ \\
\hline \multicolumn{2}{|c|}{ Sample size (n) } & 18 & 12 & 16 & 16 \\
\hline
\end{tabular}

and tropical plantations vary strikingly depending upon whether growing stock costs are included. Without growing stock costs, the medians are significantly different with temperate plantations storing carbon at net costs of $-\$ 48 \mathrm{t}^{-1} \mathrm{C}$ versus $-\$ 32 \mathrm{t}^{-1} \mathrm{C}$ for tropical plantations. With growing stock costs considered, the medians are not significantly different at $-\$ 22 \mathrm{t}^{-1} \mathrm{C}$ and $-\$ 24 \mathrm{t}^{-1} \mathrm{C}$, respectively. Medians for plantation regimes were significantly different in both instances with the integrated regimes being consistently more profitable for carbon storage than those for pulpwood (Table 8).

\section{DISCUSSION AND CONCLUSIONS}

The absolute values for costs found in this analysis are not as important as the observation that conclusions change as the economic analysis becomes more complete. Working down through Table 8 illustrates the point. If only the financial costs of the 30 plantation options were considered, the temperate plantations would appear more desirable from the standpoint of cost per ton of carbon than those in the tropics, i.e. $\$ 4$ versus $\$ 7$, and the plantation regime chosen makes little difference.

Continuing, growing stock costs would be less for tropical than for temperate plantations $\left(\$ 9 \mathrm{t}^{-1} \mathrm{C}\right.$ versus $\$ 21 \mathrm{t}^{-1} \mathrm{C}$ ), and again, no significant difference for regimes. The same trend is true for gross costs in Table 8 . This result may be driven by the shorter rotation lengths along with reduced growing stock and growing stock values for forest crops in the tropics. For short rotations, stock costs are less since the monetary resources held as growing stock are less.

Looking at revenues, the median cost per ton of carbon stored would favor temperate over tropical plantations ( $-\$ 51$ versus $-\$ 38$ ) and integrated regimes $(-\$ 56)$ over pulpwood $(-\$ 42)$. Integrated plantations with longer rotations, from this analysis, would appear to store carbon at less cost per ton of carbon.

Finally, as noted under 'Results', if only financial costs are added to the negative costs of revenues to determine a net cost per ton of carbon, the temperate plantations again appear more favorable than the tropical plantations, i.e. $-\$ 48 \mathrm{t}^{-1} \mathrm{C}$ versus $-\$ 32 \mathrm{t}^{-1} \mathrm{C}$ (Table 8 ). However, if net costs are calculated with the nonfinancial stock costs accounted for, then the difference between temperate and tropical plantations are non-significant, i.e. $-\$ 22 \mathrm{t}^{-1} \mathrm{C}$ compared to $-\$ 24 \mathrm{t}^{-1} \mathrm{C}$. Thus conclusions do change as more components of the benefits and costs of forest management are valued and added to the economic analysis.

Other costs that still need to be considered include such items as land, crop maintenance, protection, and monitoring. Regarding benefits, the analysis did utilize the direct revenues realized from the harvest of tree crops for pulpwood or sawlogs. But other direct benefits providing revenue such as water yield and recreation, and indirect benefits such as jobs and contributions to social infrastructure, must still be added. As with the addition of opportunity costs for forest stock shown above, decisions about forest management would likely change as other components are included in the analyses for the costs of storing carbon through forest management. And ultimately, as pointed out by Kramer et al. (1992), social and political concerns may eventually be deciding considerations. However, economic evaluations of forest management that incorporate more of the benefits and costs associated with carbon storage, though partial in outcome, contribute to the response to economic questions which are integral to social and political concerns. 
Acknowledgements. The research described in this paper was funded by the U.S. Environmental Protection Agency. The paper was prepared at the EPA Environmental Research Laboratory in Corvallis, Oregon, USA, through Interagency Agreement No. DW12934530/Grant PNW 91-0051. It has been subjected to the Agency's peer and administrative review process and approved for publication. Mention of trade names or commercial products does not constitute endorsement or recommendation for use.

\section{LITERATURE CITED}

Allan T., Lanly, J. P. (1991). Overview of status and trends of world forests. In: Howlett, D., Sargent, C. (eds.) Proceedings of Technical Workshop to Explore Options for Global Forestry Management, Bangkok, Thailand. International Institute for Environment and Development, London p. $17-39$

Barlowe, R (1978). Land resource economics: the economics of real estate, 3rd edn. Prentice-Hall, Englewood Cliffs

Davis, L. S., Johnson, K. N. (1987). Forest management. McGraw-Hill, New York

Dawkins, H. C. (1972). Forestry: factory or habitat? Commonwealth For. Rev. 51(4): 327-335

Devore, J., Peck, R. (1986). Statistics, the exploration and analysis of data. West Publishing Co., St. Paul, MN

Dixon, R. K., Schroeder, P. E., Winjum, J. K. (1991). Assessment of promising forest management practices and technologies for enhancing the conservation and sequestration of atmospheric carbon and their costs at the site level. EPA/600/3-91/067. October. U.S. Environmental Protection Agency, Office of Research and Development, Washington, $\mathrm{DC}$

Duerr, W. A. (1960). Fundamentals of forest economics. McGraw-Hill, New York

Duerr, W. A. (1988). Forest economics as problem solving. Orange Student Book Store, Syracuse, NY 13210, p. $16-1-30-2$

Farnum P., Timmis, R., Kulp, J.L. (1983). Biotechnology of forest yield. Science 219; 694-702

Heiner, H. (1992). Report from UNCED: the challenge of global forest management. J. For. 90(9): 28-31

Hirshleifer, J. (1970). lnvestment, interest, and capital. Prentice-Hall, Englewood Cliffs

Hughes, J. H. (1991). A brief history of forest management in the American South: implications for large-scale reforestation to slow global warming. In: Winjum, J. K., Schroeder, P. E., Kenady, M. J. (eds.) Proceedings of International Workshop on Large-Scale Reforestation. EPA/600/9-91/ 014. U.S. Environmental Protection Agency, Corvallis, OR, p. $53-68$

Kessler, W. B., Salwasser, H., Cartwright, C. W., Caplan, J. A. (1992). New perspectives for sustainable natural resources management. Ecol. Appl. 2(3): 221-225

Kramer, R., Healy, R., Mendelsohn, R. (1992). Forest valuation In: Sharma, N. P. (ed.) Managing the world's forests: looking for balance between conservation and development. Kendall/Hunt Publishing Company, Dubuque, IA 520040539, p. $237-267$
Laarman, J. G., Sedjo, R. A. (1992). Global forests: issues for six billion People. McGraw-Hill, New York

Little, 1. M. D., Mirrlees, J. A. (1974). Project appraisal and planning for developing countries. Heinemann Educational Books Ltd, London

Mather, A. S. (1990). Global forest resources. Timber Press, Portland, OR

Miller, R. E., Blaur, P. D. (1985). Input-output analysis foundations and extensions. Prentice-Hall, Englewood Cliffs

Palmer, K. L., Krupnich, A. J. (1991). Environmental costing and electric utilities planning and investment. Resources for the Future, Washington, DC. Resour. Q. 105: 1-5

Rubin, E. S., Cooper, R. N., Frosch, R. A., Lee, T. H., Marland, G., Rosenfeld, A. H., Stine, D. D. (1992). Realistic mitigation options for global warming. Science 257(5067): $148-266$

Samuelson, P. A. (1964). Economics: an introductory analysis, 6th edn. McGraw-Hill, New York

Schneider, S. H. (1989). The changing climate. Scient. Am. 261(3): 70-79

Sedjo, R. A. (1983). The comparative economics of plantation forestry: a global assessment. Resources for the Future, Washington, DC

Sinden, J. A., Worrell, A. C. (1979). Unpriced values: decisions without market prices. John Wiley \& Sons, New York

Smith, W. (1992) Managing forests under a changing climate: workshop summary. Presented at a workshop convened by the Office of Technology Assessment, Washington, DC, June $18-19$

Swisher, J. N. (1991). Cost and performance of $\mathrm{CO}_{2}$ storage in forestry projects. Biomass Bioenergy $1(6): 317-328$

Trexler, M. C. (1991). Minding the carbon store: weighing U.S. forestry strategies to slow global warming. World Resources Institute, Washington, DC

UNCED (United Nations Conference on Environment and Development) (1992). Agenda Item 9: Adoption of agreements on environment and development. UNCED A/Conf. 151/6/Rev. 1, Rio de Janeiro

USDA Forest Service (1985). Final environmental impact statement. Land and resource management plan, Ouachita National Forest. USDA Forest Service, Southern Region, Arkansas-Oklahoma, Ouachita National Forest, Hot Springs, Arkansas, 71902

Van Kooten, G. C. (1991). Economics of sequestering carbon in Canada: reforestation of denuded forest lands and afforestation of agricultural lands. In: Papers of the 1991 Annual Meeting, Western Agricultural Economics Association. Portland, Oregon, July 1991, p. 448-454

Waring, R. H., Schlesinger, W. H. (1985). Forest ecosystems: concepts and management. Academic Press, Orlando

Winch, D. M. (1971). Analytical welfare economics. Penguin Books Ltd, Harmondsworth, Middlesex, UK

Winjum, J. K., Dixon, R. K., Schroeder, P. E. (1992). Estimating the global potential of forest and agroforest management practices to sequester carbon. Wat. Air Soil Pollut. 64: $213-227$

WRI (World Resources Institute) (1990). World resources 1990-91. Oxford University Press, Oxford

Zobel, B. J., Van Wyk, G., Stahl, P. (1987). Growing exotic forests. Wiley, New York 